УДК: 75.052

ББК: 85.14

A43

DOI: $10.18688 /$ aa199-2-27

J. Albani

\title{
Beyond the Borders of Femininity: St. Eugenia and St. Athanasia in Byzantine and Post-Byzantine Art
}

Byzantine written sources contain vitae of holy women, who, disguised as monks, lived in monasteries, concealing their gender and developing male ascetic qualities [31, pp. 600-602; 37, pp. 2-3; 8, pp. 1-6; 7, p. 4]. Their vitae ${ }^{1}$ were composed probably in Egypt, Syria and Palestine, from the $5^{\text {th }}$ to the $7^{\text {th }}$ century. After the Arabs conquered these regions, Middle Byzantine hagiography focused on other types of female saints, leaving aside female cross-dressers $[11$, p. 179]. Most of the legends of holy women disguised as men were translated into Latin in the early Middle Ages and became popular also in the West [18, p. 14].

Several interpretations may be given to monastic disguises adopted by women. Since ancient times virility has been associated with positive qualities, while femininity with weakness and spiritual poverty. Transcending femininity was, according to Church Fathers, the only way for women to find soul salvation [6, p. 90; 18, pp. 16-18; 5, p. 16; 15, p. 141]. Therefore, hagiographers, overlooking the prohibitions of the Deuteronomy (22: 5), the church ${ }^{2}$, and the Theodosian Code ${ }^{3}$, praised the efforts of female cross-dressers to overcome their nature. Although legends of holy women disguised as monks have been the object of interdisciplinary study, the Byzantine iconography of this particular category of female saints, with the exception of St. Thekla [34], the earliest transvestite saint and probable model for the others, has attracted little scholarly attention so far [15, p. 138].

The aim of this paper ${ }^{4}$ is to discuss issues of gender identity and iconography in Byzantine and Post-Byzantine art ( $9^{\text {th }}-16^{\text {th }}$ centuries) based on the figure of the transvestite female saint. Using as case studies St. Eugenia and St. Athanasia ${ }^{5}$ I will try to explore the visual language

These legends exist in Greek, Coptic, Ethiopic, Syriac, Latin, and Arabic versions. See [3, p. 50; 40, p. 142; 18, pp. 14-15].

The Council of Gangra (c. 341), in Paphlagonia, condemned, among others, the cross-dressing of women favoured by the radical ascetic tendencies of the Eustathians. The concluding canons of the Council forbade women from wearing men's garments (canon 13) and cutting their hair (canon 17) [28; 33, p. 92; 40, p. 147; 8, pp. 21-22]. On the Council in Trullo forbidding men and women from cross-dressing in popular feasts with dances, see [17].

3 The Theodosian Code also prohibited female tonsure [40, p. 147].

4 I am particularly indebted to Dr. Pavlos Flourentzos, Director Emeritus of the Department of Antiquities, Cyprus, for giving me permission to publish photographs of depictions of St. Athanasia in painted churches of Cyprus. I would also like to thank Mr. Dimitrios Doumas for editing the text.

It is, however, worth mentioning that Byzantine hagiography contains at least ten more detailed vitae of female cross-dressers (Eyphrosyne/Smaragdos, Hilaria/Hilarion, Marina/Marinos, Pelagia/Pelagios, Margarita/Pelagios, Apollinaria/Dorotheos, Matrona of Perge/Babylas, Theodora of Alexandria/Theodore, Anastasia/Anastasios, Glaphyra) [8, pp. 2-7; 40, p. 141]. 
used by Byzantine artists to depict them, in comparison with Western imagery, and shed light on the role of Constantinople, the empire's Capital, in shaping their iconography. I will also examine the symbolic meaning of the trans-hagiographic portraits of St. Athanasia in the otherwise conservative iconographic programme of Byzantine and Post-Byzantine churches in Cyprus tracing the origins of her particular popularity on the island.

According to her legend [9, cols. 339-344; 22, cols. 609-652], St. Eugenia was the beautiful and learned daughter of Philip, prefect

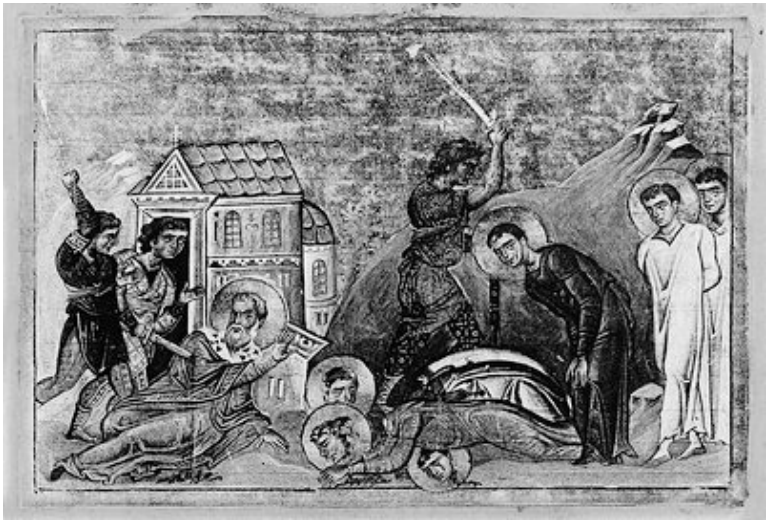

Fig. 1. Martyrdom of Sts. Philip, Eugenia, Protas, and Hyakinthos. Miniature. Menologion of Basil (Cod. Vat. Gr. 1613, p. 270). Around 1000. Biblioteca Apostolica Vaticana, Rome. (C) 2019 Biblioteca Apostolica Vaticana. By permission of Biblioteca Apostolica Vaticana, with all rights reserved of Alexandria. Having instructed herself in the Christian faith and knowing that her pagan father would oppose to her new religion, she fled from her parental house and, disguised as a man, entered a monastery accompanied by her servants Protas and Hyakinthos. She lived there an exemplary life, received from God the gift of healing the sick, and later became an abbot. Once, a young rich woman, named Melanthia, cured of an illness by Eugenia and not suspecting that the handsome abbot Eugenios was a woman, made sex advances to him, which Eugenia rejected. Melanthia accused Abbot Eugenios publicly of adultery and the holy crossdresser was taken to court, where she faced her father as the judge. At the trial, Eugenia, tearing her garments, revealed her real female identity and was exonerated, while her father turned into a Christian and became Bishop of Alexandria. After her father was executed for having adopted the Christian faith, Eugenia with her mother and brothers moved to Rome, where she converted many people to Christianity. During the persecution of Emperor Valerian against Christians Protas and Hyakinthos were beheaded on the $11^{\text {th }}$ of September, 258, and Eugenia was also decapitated on the Feast of the Nativity. Her feast day is celebrated on the $24^{\text {th }}$ of December in the Orthodox Church and on the $25^{\text {th }}$ of December in the Roman Catholic Church.

St. Eugenia is very rarely depicted in Byzantine art. In Early Byzantine mosaics in the Basilica of Sant' Apollinare Nuovo in Ravenna (c. 561) (Ill. 50) and in the Euphrasian Basilica in Poreč ( $6^{\text {th }}$ century) [44, fig. 5.4] she is shown as a young beautiful female saint and identified through an inscription ${ }^{6}$. The inclusion of her vita in the $10^{\text {th }}$-century menologion by Symeon Metaphrastes [11, p. 180] and her depiction in the Menologion of Basil, a richly illustrated Constantinopolitan manuscript for Emperor Basil II (976-1025), in the Biblioteca Apostolica Vaticana (cod. Vat. Gr. 1613, p. 270), imply that her worship was well established in the Capital during the Middle Byzantine period. The miniature in the Menologion of Basil (Fig. 1) depicts the decapitation of the saint and her two companions in combination with the martyrdom of 
her father, Bishop Philip. Although on the day of her execution Eugenia was not disguised as a man, she is portrayed with short hair, similar in appearance to the eunuchs Protas and Hyakinthos. Thus, the miniature combines visually the scene of Eugenia's martyrdom - a typical image for a Byzantine menologion - with her cross-dressing earlier in life, probably to emphasize the overcoming of her female nature.

The $11^{\text {th }}$-century illuminated manuscript $\Delta 51$ at the Great Lavra Monastery, on the Holy Mount Athos, containing vitae of saints commemorated in December, also includes a miniature (fol. 131 $\beta$ ) with the martyrdom of St. Eugenia [32, fig. 116] who is no more depicted as a unisex figure. Moreover, Eugenia $(H / A / \Gamma / I / A-E / Y / \Gamma / E / N / I / A)$ is depicted half-length, as a young female saint in a medallion, in the narthex of the katholikon of the monastery of Hosios Loukas [4, p. 213, fig. 1; 44, fig. 5.5], in Boeotia, the mosaic decoration of which is related to the art of Constantinople. Similarly, in scenes of her martyrdom in Western art, Eugenia appears fully feminized. There are only two medieval Western artworks known so far which show St. Eugenia disguised as a monk: a capital (c. 1120) at the monastery of Sainte-Madeleine in Vézelay $\left[15\right.$, figs. $8-10 ; 21$, p. 222, no. 4 ] and a late $13^{\text {th }}$-century Catalan altar frontal by the Master of Soriguerola [44, pp. 225-226, fig. 5.19], now in the Musée des Arts Décoratifs in Paris. In both works St. Eugenia is depicted tonsured, exposing her breast to reveal her true identity at the courtroom. Probably related to the ideals of the Gregorian Reform (mid- $11^{\text {th }}$ first decade of the $12^{\text {th }}$ century), the Eugenia capital had a pronounced edifying role, highlighting patterns of denial of sexual temptation, a key issue of monastic life [21, pp. 221-222].

The second transvestite holy woman in question, St. Athanasia, also belonged to a high social class, according to the Life of Andronikos and Athanasia ${ }^{7}$, probably a $6^{\text {th }}$-century tale, traditionally ascribed to Daniel of Sketis [31, p. 600; 2, pp. 396-397; 11, p. 239]. She was married to Andronikos, a wealthy and pious banker from Antioch. After the sudden death of their two children, the two spouses took monastic vows in Egypt and thus lived separately for twelve years. Due to God's dispensation they met each other on their way to the loca sancta. Since, for safety reasons, Athanasia was disguised as a monk, Andronikos did not recognize her and she did not reveal her true identity to him, although she had identified him. After their pilgrimage Athanasia, constantly disguised as a monk, and Andronikos shared the same cell in the monastery of Oktokaidekaton for twelve years. The true identity of Athanasia was revealed only after her death through a pittakion (i.e. a short text) left by her. Andronikos died soon afterwards and they were buried side by side at Oktokaidekaton. The feast day of the two saints is celebrated on the $9^{\text {th }}$ of October and their dormition on the $2^{\text {nd }}$ of March [9, cols. 125-126, verses 33-34, col. 501, verses 21-22]. A kanon in their honour by Demetrios Stoudites [2, p. 603] provides evidence for their worship in the Middle Byzantine period in the Stoudios Monastery, one of the most important religious foundations in Constantinople.

For the Greek versions of the tale of Sts. Andronikos and Athanasia (BHG 121 and BHG 122), in the cod. Gr. 1598, fol. 247v-252 (993) and cod. Coislin 283 (11 $1^{\text {th }}$ century), 264v-267 of the Bibliothèque Nationale, Paris, as well as the Syrian versions in the cod. Add.14649, fol. 96, in London, and cod. Syr. 235, fol. 204, in Paris, see [3, pp. 370-384, 401-406]. For another Greek version of the Life (BHG 123a) in the codex Urbani $36\left(10^{\text {th }}-11^{\text {th }}\right.$ centuries), fols. $183-193 \mathrm{v}$, in the Biblioteca Franzoniana, Genova, see [1, pp. 4, 256-277]. 
Moreover, the depiction of Sts. Athanasia and Andronikos in the manuscript Syn. Gr. 183, fol. 142r, in the State Historical Museum of Moscow [42, figs. 9, 11; 43, figs. 186, 188], one of the few surviving editions of the so-called Imperial Menologion, bears witness to the worship of the two saints in the imperial court in the $11^{\text {th }}$ century since the texts of this menologion were read out in the emperor's presence, in one of the numerous chapels of the Great Palace. This edition, which reveals a close iconographic and stylistic affinity with the Menologion of Basil II, contains four homilies and fifty-five vitae of saints commemorated in February and March [42, p. 131, no. 2]. Each life is followed by a short prayer for the well-being and salvation of a Byzantine emperor, probably Michael IV, the Paphlagonian (1034-1041) ${ }^{8}$. Athanasia and Andronikos are portrayed in prayer in front of the porch of a building with a row of arched windows, which probably belonged to the cells of a monastery. Athanasia is shown disguised as a monk, wearing the analabos, a distinctive

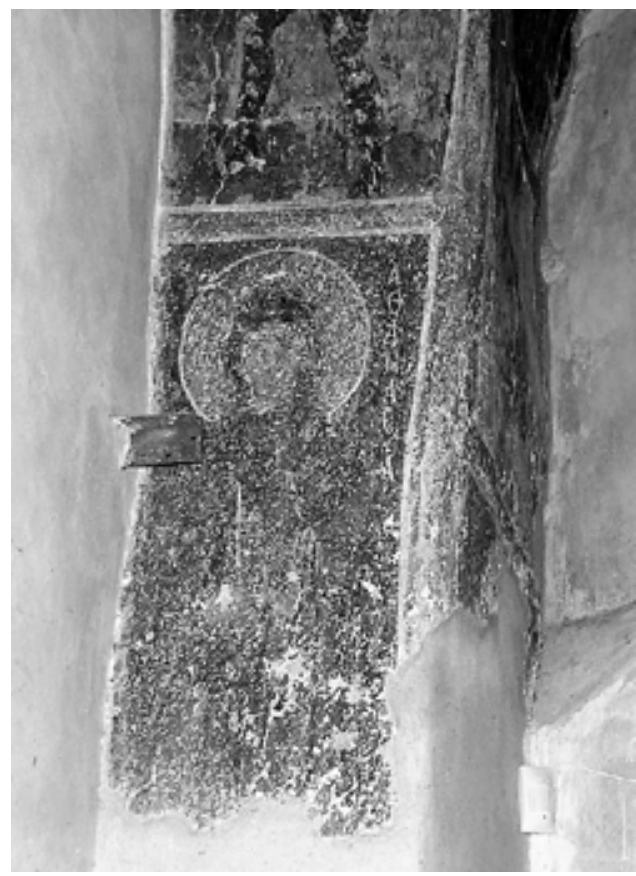

Fig. 2. St. Athanasia. Wall painting. Early 12th century. Katholikon of the monastery of Hagios Nikolaos tes Steges in Kakopetria, Cyprus. (C) Department of Antiquities, Cyprus. Photo by Jenny P. Albani garment of the Great Schema monks and nuns, the highest grade of Orthodox monasticism, and a turban-like koukoulion typical of depictions of Egyptian and Syrian monks.

The cult of the two saints is also attested in Cyprus, where many small churches are dedicated to them, and they appear in frescoes and icons. The earliest, securely identified image of St. Athanasia in Cyprus is her full-length inscribed portrait in the soffit of the northwest arcosolium in the narthex of the katholikon of the monastery of Hagios Nikolaos tes Steges in Kakopetria (Fig. 2). It belongs to a fresco layer of the early $12^{\text {th }}$ century with a representation

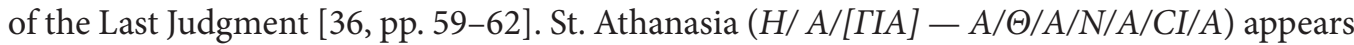
in a monastic habit similar to that of her portrait in the Moscow manuscript of the Imperial Menologion. Her inclusion in a pictorial programme with eschatological content reveals the local belief in her intercessory role, probably due to her ascetic qualities and also her name "Athanasia", which in Greek means "immortality".

A $13^{\text {th }}$-century depiction of St. Athanasia is preserved in the katholikon of the monastery of Hagios Ioannes Lampadistes in Kalopanagiotes, dedicated to St. Herakleidios (Fig. 3) [36,

8 On the two surviving illuminated copies of the Imperial Menologion, namely the Cod. W 521 at the Walters Art Museum in Baltimore and the Cod. Syn. gr. 183 at the State Historical Museum in Moscow, see $[42 ; 43]$ (with the previous bibliography). 

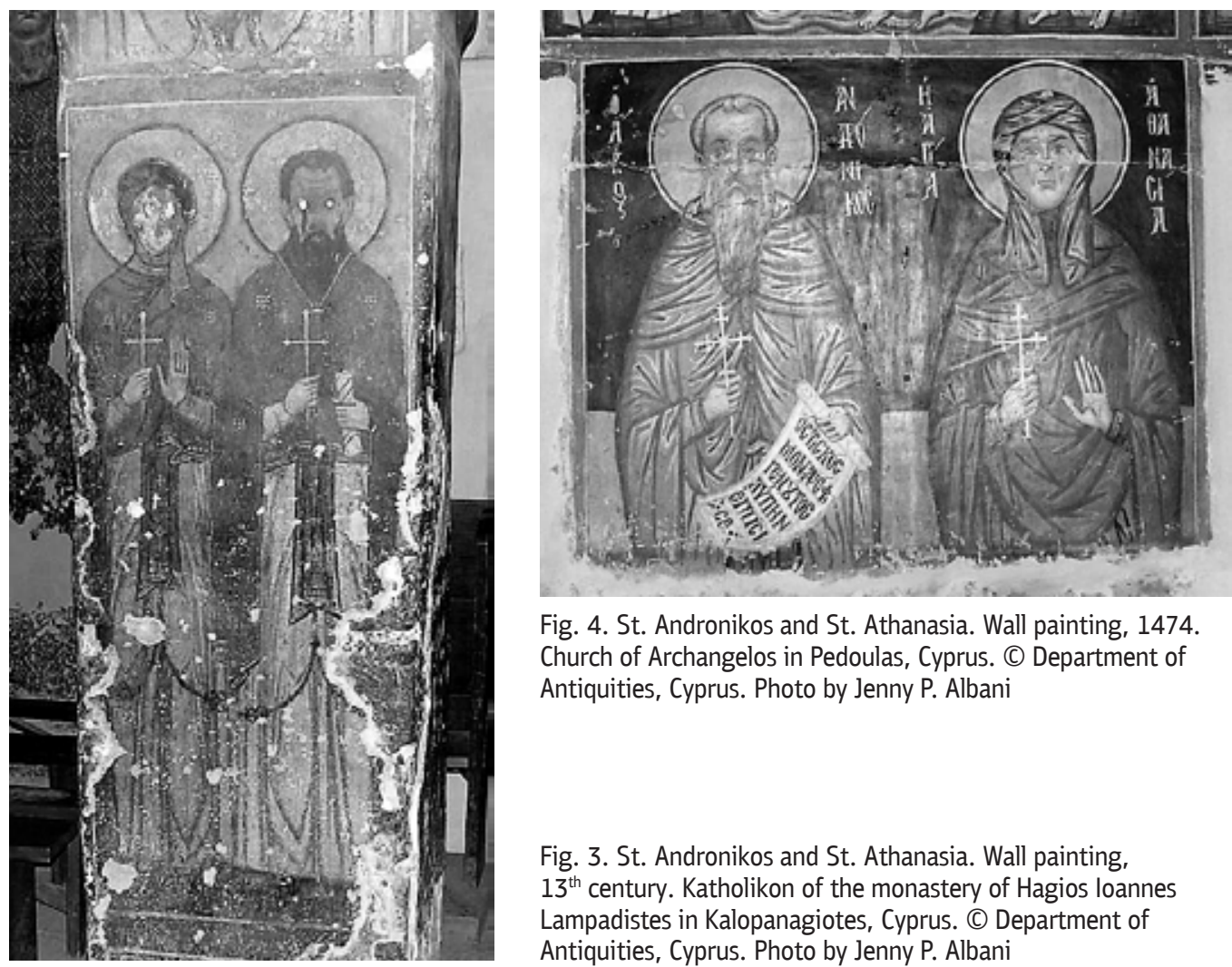

Fig. 4. St. Andronikos and St. Athanasia. Wall painting, 1474. Church of Archangelos in Pedoulas, Cyprus. (C) Department of Antiquities, Cyprus. Photo by Jenny P. Albani

Fig. 3. St. Andronikos and St. Athanasia. Wall painting, $13^{\text {th }}$ century. Katholikon of the monastery of Hagios loannes Lampadistes in Kalopanagiotes, Cyprus. (C) Department of Antiquities, Cyprus. Photo by Jenny P. Albani

p. 298] integrated into an iconographic narrative which underlines her intercessory role. St. Athanasia, with a similar iconographic rendering as in Kakopetria, appears next to her husband, on the eastern side of the northwest pier of the nave, facing the Deesis which is shown on the corresponding side of the southwest pier. Opposite Sts. Andronikos and Athanasia, on the west side of the northeast pier, the Virgin Paraklesis is depicted in dialogue with Christ, painted on the western side of the southeast pier, asking him, according to the text on her scroll, for the remission of human sins.

The painted decoration of the church of Panagia in Moutoullas, sponsored by John Gerakiotes and his wife Irene in 1280, also contains a portrait of St. Athanasia ([H AГIA A]/ $\Theta A / N A / C H / A$ ) [36, pp. 323-325, 328; 35, pp. 102-103; 23, pp. 172-173, fig. 24; 4, fig. 7], painted on the western wall of the nave, to the left of the entrance, between those of St. Mavra, a local saint of Cyprus [25, pp. 251-252; 4, pp. 217-218], and St. Andronikos. To the right of the door three more female saints, Barbara, Marina and Anastasia Pharmakolytria (i.e. the poison-curer), are depicted. St. Athanasia is painted with an oriental koukoulion and a short beard, a peculiar iconographic detail which can be paralleled in Western hagiography, namely by the legends of Sts. Galla, Paula, and Wilgefortis. In their effort to evade a forced marriage, these holy women are supposed to have grown beards either because of some organic change or by divine intervention $[8$, p. $16 ; 39$, pp. 9-11; 41]. 


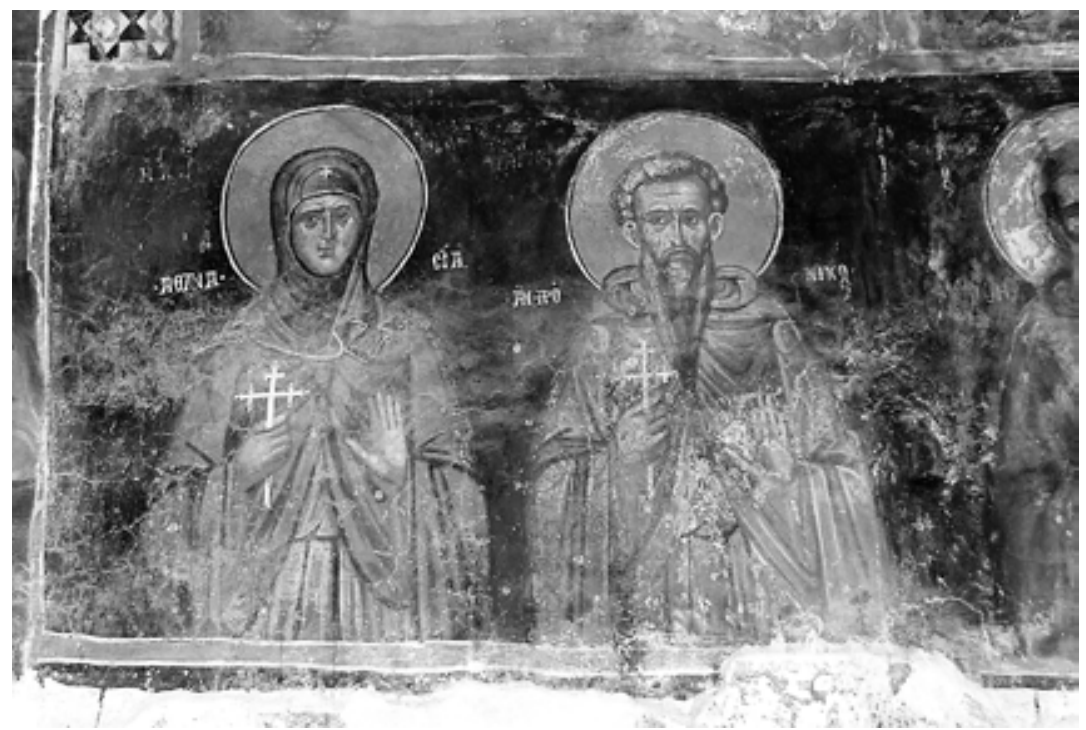

Fig. 5. Sts. Andronikos and Athanasia. Wall painting. $15^{\text {th }}$ century. Church of Chryseleousa in Empa, Cyprus.

(C) Department of Antiquities, Cyprus. Photo by Jenny P. Albani

Portraits of St. Athanasia are also included in two $15^{\text {th }}$-century church decorations, firmly dated by dedicatory inscriptions: in Archangelos in Pedoulas, from 1474, and in Hagios Mamas in Louvaras, from 1495. The building and decoration of the church in Pedoulas were sponsored by the priest Basileios Hamados, his wife and two daughters. The dedicatory inscription mentions also the painter Philip Goul [36, pp. 331-332, 337; 35, Donors, pp. 112-114]. St. Athanasia $(H / A / \Gamma I / A-A / \Theta A / N A / C I / A)$ and her husband $(O / A / \Gamma I / O C-A N / \Delta P O / N I /$ $K O C$ ) are portrayed on the west wall to the left of the door (Fig. 4), while to the right of the entrance Sts. Constantine and Helen, who enjoyed a fervent cult in Cyprus [4, pp. 222-224], are depicted. St. Athanasia is shown as a nun, holding a cross and making the gesture of prayer with her left hand. Her blue wimple reveals influences from the religious attire of Western nuns 9 . In the church of Louvaras, painted with funds provided by John Kromides and George Pelekanos, councillors of the village, and their wives [36, pp. 246-247; 35, pp. 110-111], images of St. Athanasia ( $\left.H A\left(\gamma^{\prime} \alpha\right) / A \Theta A N A-C I A\right)$ and St. Andronikos $(O A(\gamma l o \varsigma) / A N \triangle P O$ - NIKOC) (Ill. 51) appear on the western part of the north wall together with portraits of St. John the Faster, Patriarch of Constantinople, St. Therapon the Wonderworker, a popular saint in Cyprus, and St. Kornoutos. The badly preserved figure of St. Athanasia is rendered with a headdress similar to that of her portrait in Pedoulas.

Also fragmentarily preserved is the $15^{\text {th }}$-century portrait of St. Athanasia next to that of St. Andronikos, on the western part of the south barrel vault of the church of Chryseleousa in Empa. The spirituality and ascetic qualities of the holy couple are emphasized by their depiction close to the figure of St. John the Theologian, apostle, evangelist and hermit. Two more 
late $15^{\text {th }}$-century images of both saints ${ }^{10}$ (Fig. 5) in a similar symbolic context appear on the northern part of the western barrel vault of the church among prominent figures of Orthodox monasticism, namely Sts. Euthymios, Theodosios, Ephraim the Syrian, Sabbas, Anthony, Cosmas and Joseph the Poets, Theodore of Stoudios, and Symeon Stylites.

A fragmentarily preserved portrait of St. Athanasia in the church of Hagios Theodosios at Achelia, appears next to those of St. Andronikos and St. Anastasia Pharmakolytria, in the north part of the west cross arm [29, p. 94]. Although dated to the $15^{\text {th }}$ century, these frescoes may have been earlier works, since the detail of their halos decorated with pearls is a typical feature of $13^{\text {th }}$-century icons [24, p. 119, figs. 68-69]. Images of the Apostles Peter and Paul with two deceased are facing those of the three saints.

St. Athanasia was highly venerated in Cyprus also during the $16^{\text {th }}$ century, as evidenced by her depictions in church decorations and icons. Two full-length portraits of the saint are included in the painted decorations of Hagios Sozomenos and Archangelos (or Panagia) in Galata, both signed by the painter Symeon Axentes and dated by inscriptions to 1513 and 1514 respectively. The first project was sponsored by a group of fourteen villagers, including two priests. Sts. Athanasia and Andronikos are portrayed in the soffit of the northern door as guardians of

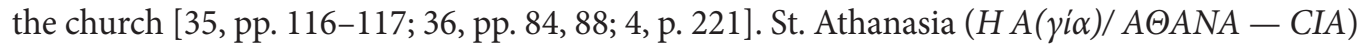
is painted in the typical habit of a Byzantine nun. A similar portrait of the saint in prayer appears in the church of Archangelos, built and painted under the patronage of the probably Hellenized Zacharia family [36, pp. 90-92; 35, pp. 117-120]. To the left of the west door the figures of St. Athanasia ( $\left.H A\left(y_{i} \alpha\right) A \Theta A-N A C I A\right)$ and St. Andronikos $(O A(\gamma l o \varsigma) / A N \triangle P O-K O C)$ are arranged within an arcade (Ill. 52), an iconographic motif with a pronounced funerary symbolism, since it harks back to Early Christian architectural-style sarcophagi. Part of the same arcade with the portraits of Sts. Marina and Paraskevi, two very popular saints in Cyprus [25, pp. 252-253; 4, pp. 217, 221], are arranged on the other side of the door.

The last portrait of this brief survey is included in the painted decoration of the church of Timios Stavros (i.e. Holy Cross) in Kyperounta. The full-length figures of St. Athanasia and St. Andronikos facing each other appear in the intrados of the north recess, the wall paintings of which are dated by an inscription to 1521 [36, p. 219]. At the center of the conch [4, fig. 30] appears the Holy Cross, symbol of salvation, surrounded by scenes of its discovery. In the bottom left, the donor, monk Akakios, supplicates to the Holy Cross, the saints Cosmas and Damian and the holy figures of the Sanctuary. On either side of the conch, St. Peter, with the keys of Paradise, above the scene of the Lamentation, and the Virgin "Eleousa" are depicted looking towards the Sanctuary. The inscribed scroll of the Virgin contains a request to Christ for the salvation of mankind. Within this eschatological iconographic programme with a con-

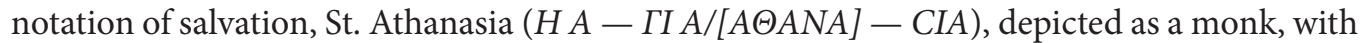
the characteristic oriental headdress, holding a cross in her right hand, makes a gesture of prayer with her left [36, fig. 127].

The examination of Byzantine and Post-Byzantine depictions of St. Eugenia and St. Athanasia reveals that the iconographic rendering of these holy cross-dressers was by no means

10 Inscriptions: $\mathrm{H} \mathrm{A}\left(\gamma^{\prime}\right.$ a $) / \mathrm{A} \Theta \mathrm{ANA}-\mathrm{CIA}$ and [O AГIOC]/ AN $\triangle \mathrm{PO}-\mathrm{NIKOC}$. On the date of these portraits, see [29, p. 92]. 
established, but rather a field of experimentation for painters. It seems, however, that Middle Byzantine artists in Constantinople had developed a pictorial language of representing the disguise of both saints, as evidenced by the Menologion of Basil II and the Moscow Imperial Menologion, two manuscripts securely related to emperors.

St. Eugenia, albeit very popular in Western art, is rarely portrayed in Byzantium. Though in the Menologion of Basil, in the Biblioteca Apostolica Vaticana, St. Eugenia is shown as eunuch, in the manuscript $\Delta 51$ of the Great Lavra Monastery and the Early and Middle Byzantine mosaics in Sant' Apollinare Nuovo, the Euphrasian Basilica, and Hosios Loukas there is no visual reference to her disguise. The unstable iconography of Eugenia's portraits, the majority of which do not show her gender inversion, probably derives from the artists' difficulty to manipulate visually a subject that goes beyond hagiographic stereotypes, disrupts social conventions, and is associated with a practice prohibited by the Church. The Byzantine Church prefers to represent Eugenia as a Christian martyr rather than a holy cross-dresser since she spent only a part of her life in the monastery. Similar ambiguity is observed in the early iconography of St. Thekla, and also in Western medieval depictions of transvestite saints [34, pp. 119-133; 15, pp. 138-143].

St. Athanasia appears only in one Byzantine manuscript known so far, the Moscow Imperial Menologion, but often in painted Orthodox churches of medieval Cyprus, an island hosting several social and ethnic groups which corresponded to a diversity of identities ${ }^{11}$. Her early portraits in Cypriot monumental painting are associated with monastic circles and influenced by metropolitan models, as attested by the iconographic resemblance of her portraits in Kakopetria and Kalopanagiotes to that in the Moscow Imperial Menologion. Athanasia was not a martyr and her sainthood is based exclusively on her life as a monk together with St. Andronikos, her husband. Therefore, she is represented in Cypriot churches either as a eunuch monk of the Christian Orient ${ }^{12}$ or as a nun ${ }^{13}$ with no visual reference to her gender inversion. Her cross-dressing is especially pronounced at the village church of Panagia in Moutoullas where she is depicted with a short beard. The monastic habit and the pairing of her image to that of St. Andronikos are standard elements of her iconography aiding viewers to recognize her.

The depiction of St. Athanasia next to her husband Andronikos emphasizes the indivisible companionship of the two spouses ${ }^{14}$ and calls to imitation. The belief in the power of their spirituality is evidenced by their depiction as intercessors in eschatological contexts as well as close to prominent figures of Eastern monasticism. Moreover, the combination of the images of the two spouses with healing saints, such as Anastasia Pharmakolytria, Cosmas and Damian, probably reflects a tradition associated with their own healing properties. A text on their life, partly preserved in the late $16^{\text {th }}$-century manuscript Bollandien $1009^{15}$, in

11 On the cultural and social history of Cyprus under Frankish rule, see [27].

12 In the miniature of the Moscow Imperial Menologion and the wall paintings of Hagios Nikolaos tes Steges in Kakopetria, the katholikon of Hagios Ioannes Lampadistes in Kalopanagiotes, and Timios Stavros in Kyperounta.

${ }_{13}$ In the wall paintings of Archangelos in Pedoulas, Hagios Mamas in Louvaras, Chryseleousa in Empa, Hagios Sozomenos in Galata and Archangelos in the same village.

14 On the theme of marriage in Byzantine hagiography, see [19, pp. 132-134, 143].

15 This manuscript consists of two mutilated manuscripts joined to each other. 
the Bibliothèque des Bollandistes in Brussels, mentions (fols. 54-69v) healing miracles of St. Andronikos [16, p. 254]. Moreover, in an enkomion in honour of Sts. Athanasia and Andronikos on their feast day (BHG 123), St. Neophytos the Recluse, who also enjoyed a particularly popular cult in Cyprus, accredits their relics with healing miracles, and also refers to the healing qualities of the myrrh which sprang from their images in a church dedicated to them [10, p. 179; 23, pp. 196-197, no. 103; 4, p. 217, no. 31]. St. Neophytos himself had received a small glass flask with this miraculous myrrh, healing people and animals as well, which was flowing from a part of the relic of St. Andronikos in his church in Antalya, Asia Minor $[10,180]$. Does this information by Neophytos ${ }^{16}$ reflect a generic practice associated with the transfer of the healing liquid from Antalya to Cyprus? This is a plausible hypothesis, if we consider the close commercial relations of Cyprus and the Asia Minor coast [14, pp. 122-128] and a depiction of St. Andronikos with a flask on a $13^{\text {th }}-14^{\text {th }}$-century icon from the church of St. Andronikos in Kalopanagiotes, now in the Icon Museum of the monastery of St. John Lampadistes [13, fig. $87 ; 38$, p. 265, no. 136]. It is also worth noting that, according to a Modern Greek folk tradition, water flowing near a church of St. Andronikos in Cyprus could heal skin and animal diseases [30, p. 113; 25, p. 247]. The posthumous healing powers of the two saints, their intercessory qualities, and values associated with their relationship may provide the clue for understanding of the remarkable dispersal of their cult in Cyprus. Moreover, it offers an explanation for the inclusion of images of St. Athanasia, a holy cross-dresser and, therefore, an ambiguous persona par excellence, within the iconographic programmes of Cypriot churches.

\section{References}

1. Alwis A. P. Celibate Marriages in Late Antique and Byzantine Hagiography. The Lives of Saint Julian and Basilissa, Andronikos and Athanasia, and Galaktion and Episteme. London; New York, Continuum International Publishing Group Publ., 2011. 352 p.

2. Beck H.-G. Kirche und theologische Literatur im Byzantinischen Reich. Munich, C. H. Beck'sche Verlagsbuchhandlung Publ., 1959. 851 p. (in German).

3. Clugnet L. (ed.). Vie et récits de l’abbé Daniel, de Scété (VI siècle). Revue de l'Orient Chrétien 1900, vol. 5, pp. 49-73, 370-406 (in French).

4. Connor C. L. Female Saints in Church Decoration of the Troodos Mountains in Cyprus. Medieval Cyprus: Studies in Art, Architecture, and History in Memory of Doula Mouriki. Princeton N. J., Princeton University in association with Princeton University Press Publ., 1999, pp. 211-240.

5. Connor C. L. Women of Byzantium. New Haven; London, Yale University Press Publ., 2004. 413 p.

6. Constantinou St. Female Corporeal Performances. Reading the Body in Byzantine Passions and Lives of Holy Women. Uppsala, Acta Universitatis Upsaliensis Publ., 2005. 225 p.

7. Davis S. J. Crossed Texts, Crossed Sex. Intertextuality and Gender in Early Christian Legends of Holy Women Disguised as Men. Journal of Early Christian Studies, 2002, vol. 10, no 1, pp. 1-36.

8. Delcourt M. Le complexe de Diane dans l'hagiographie chrétienne. Revue de l'histoire des religions, 1958, vol. 153, no 1, pp. 1-33 (in French).

9. Delehaye H. (ed.). Synaxarium Ecclesiae Constantinopolitanae. Propylaeum ad Acta Sanctorum Novembris. Brussels, Apud Socios Bollandianos Publ., 1902. 1255 cols. (in Greek).

10. Delehaye H. Saints de Chypre. Analecta Bollandiana, 1907, vol. 26, pp. 161-301 (in French).

11. Delierneux N. Virilité physique et sainteté feminine dans l'hagiographie orientale du IV au VII ${ }^{e}$ siècle. Byzantion, 1997, vol. 67, no 1, pp. 179-243 (in French).

\footnotetext{
16 Moreover, St. Neophytos asks Sts. Andronikos and Anastasia to mediate to Christ for his salvation [10,
} p. 180]. 
12. Drakopoulou Eu. Saints Constantine and Helen. Eikones apo tis orthodoxes koinotetes tes Albanias (Icons from the Orthodox Communities of Albania). Athens, Europaiko Kentro Byzantinon kai Metabyzantinon Mnemeion, Mouseio Byzantinou Politismou Publ., 2006, pp. 74-77 (in Greek).

13. Eliades I. A. (ed.). Maniera Cypria. The Cypriot Painting of the $13^{\text {th }}$ Century between Two Worlds. Lefkosia, Archbishop Makarios III Foundation; Cyprus Tourism Organization Publ., 2017. 111 p.

14. Gerolymatou M. Agores, emporoi kai emporio sto Byzantio $\left(9^{o s}-12^{o s}\right.$ ai.) (Markets, Merchants, and Trade in Byzantium ( $9^{\text {th }}-12^{\text {th }}$ Centuries)). Athens, National Hellenic Research Foundation Publ., 2008. 304 p. (in Greek).

15. Grayson S. Disruptive Disguises: The Problem of Transvestite Saints for Medieval Art, Identity and Identification. Medieval Feminist Forum, 2009, vol. 45, no. 2, pp. 138-174. Available at: https://doi. org/10.17077/15368742.1814 (accessed 5 January 2019).

16. Halkin F. Un Recueil de Légendes hagiographiques: Le MS. Bollandien 1009. Byzantinische Zeitschrift, 1951, vol. 44, pp. 253-257 (in French).

17. Herrin J. "Femina Byzantina": The Council in Trullo on Women. Dumbarton Oaks Papers, 1992, vol. 46, pp. 97-105.

18. Hotchkiss V. R. Clothes Make the Man: Female Cross Dressing in Medieval Europe. New York; London, Garland Publishing, Inc. Publ., 2000. 201 p.

19. Kazhdan A. Byzantine Hagiography and Sex in the Fifth to Twelfth Centuries. Dumbarton Oaks Papers, 1990, vol. 44, pp. 131-143.

20. Koslin D. Clothing for Religious Women. Women and Gender in Medieval Europe. An Encyclopedia. New York; London, Routledge Publ., 2006, pp. 149-150.

21. Loos-Noji P. Temptation and Redemption: A Monastic Life in Stone. Equally in God's Image. Women in the Middle Ages. New York; San Francisco; Bern; Frankfurt am Main; Paris; London, Peter Lang Publ., 1990, pp. 220-232.

22. Migne J.-P. (ed.). Symeonis Logothetae Metamphrastae, opera omniae. Patrologiae Cursus Completus. Series Graeca, vol. 116. Paris, Apud Gariner Fratres, editores et J.-P. Migne successores Publ., 1864. 1428 cols. (in Greek and Latin).

23. Mouriki D. The Wall Paintings of the Church of the Panagia at Moutoullas, Cyprus. Byzanz und der Westen. Studien zur Kunst des europäischen Mittelalters. Vienna, Verlag der Österreichischen Akademie der Wissenschaften Publ., 1984, pp. 171-213.

24. Mouriki D. Icons from the $12^{\text {th }}$ to the $15^{\text {th }}$ Century. Sinai. Treasures of the Monastery of Saint Catherine. Athens, Ekdotike Athenon Publ., 1990, pp. 102-124, 150-202, 384-387.

25. Mouriki D. The Cult of Cypriot Saints in Medieval Cyprus as Attested by Church Decorations and Icon Painting. The Sweet Land of Cyprus. Papers Given at the Twenty-Fifth Jubilee Spring Symposium of Byzantine Studies, Birmingham, March 1991. Nicosia, The Cyprus Research Centre for the Society for the Promotion of Byzantine Studies Publ., 1993, pp. 237-277.

26. Mouriki D. Portraits of St Theodosia in Five Sinai Icons. Thymiama ste mneme tes Laskarinas Mpoura (Incense in the Memory of Laskarina Boura). Athens, Mouseio Mpenaki Publ., 1994, pp. 213-219.

27. Nicolaou-Kornari A.; Schabel Chr. (eds.). Cyprus. Society and Culture 1191-1374. Leiden; Boston, Brill Publ., 2005. 403 p.

28. Papadakis A. Gangra, Local Council of. The Oxford Dictionary of Byzantium. New York; Oxford, Oxford University Press Publ., 1991, vol. 2, pp. 821-822.

29. Papageorgiou A. Hiera Metropolis Paphou. Historia kai Techne. 1950 chronia apo ten hidryse tes (Holy Metropolis of Paphos. History and Art. 1950 Years since Its Foundation). Nicosia, H. Metropolis Paphou Publ., 1996. 225 p. (in Greek).

30. Paraskevopoulou M. Researches into the Traditions of the Popular Religious Feasts of Cyprus. Nicosia, Zavallis Press Publ., 1982. 176 p.

31. Patlagean E. L'histoire de la femme déguisée en moine et l'évolution de la sainteté féminine à Byzance. Studi Medievali, 1976, ser. 3, vol. 17, pp. 597-623 (in French).

32. Pelekanides S. M.; Chrestou P. K.; Mauropoulou-Tsioume Ch.; Kadas S. N.; Katsarou Ai. Oi Thesauroi tou Hagiou Orous (The Treasures of the Holy Mountain), vol. 3. Athens, Ekdotike Athenon Publ., 1979. 327 p. (in Greek).

33. Saradi-Mendelovici H. L'“infernitas sexus” présumée de la moniale byzantine: Doctrine ascétique et pratique juridique. Women and Byzantine Monasticism. Proceedings of the Athens Symposium 1988. Athens, Canadian Archaeological Institute at Athens Publ., 1992, pp. 87-97 (in French). 
34. Semoglou A. He Thekla sten Auge tou Christianismou. Eikonographike Melete tes Protes Gynaikas Martyra sten Techne tes Hysteres Archaiotetas (Thekla at the Dawn of Christianity. An Iconographic Study of the First Woman Martyr in the Art of Late Antiquity). Thessalonike, Aristoteleio Panepistemio Thessalonikes, Kentro Byzantinon Ereunon Publ., 2014. 155 p. (in Greek).

35. Stylianou A.; Stylianou J. Donors and Dedicatory Inscriptions, Supplicants and Supplications in the Painted Churches of Cyprus. Jahrbuch der Österreichischen Byzantinischen Gesellschaft, 1960, vol. 9, pp. 97-128.

36. Stylianou A.; Stylianou J. The Painted Churches of Cyprus. Treasures of Byzantine Art. London, Trigraph Publ., 1985. 517 p.

37. Talbot A.-M. (ed.). Holy Women in Byzantium. Ten Saints' Life in English Translation. Washington D.C., Dumbarton Oaks Research Library and Collection Publ., 1996. 378 p.

38. Talbot Rice D.; Gunnis R.; Talbot Rice T. The Icons of Cyprus. London, George Allen and Unwin Publ., 1937. $287 \mathrm{p}$.

39. Villemur F. Saintes et travesties du Moyen Âge. Clio. Femme, Genre, Histoire, 1999, vol. 10, Femmes travesties: un "mauvais" genre, pp. 1-23. Available at: https://journals.openedition.org/clio/253 (accessed 10 January 2019) (in French).

40. Vogt K. "The Woman Monk". A Theme in Byzantine Hagiography. Digitalt Universitetsbiblioteket $i$ Bergen. Available at: https://digitalt.uib.no/bitstream/handle/1956.2/2997/The\%20woman\%20monk_ Vogt.pdf?sequence $=1$ (accessed 10 January 2019).

41. Wallace L. Bearded Woman, Female Christ: Gendered Transformations in the Legends and Cult of Saint Wilgefortis. Journal of Feminist Studies in Religion, Spring 2014, vol. 30, no. 1, pp. 43-63.

42. Zakharova A. V. Miniatures of the Imperial Menologia. Nea Rhome. Rivista di ricerche bisantinistiche, 2011, vol. 7, pp. 131-153.

43. Zakharova A. V. Imperial Menologia. Vizantiyskaia miniatiura. Vtoraia polovina X - nachala XII veka (The Byzantine Miniature from the Second Half of the $10^{\text {th }}$ to Early $12^{\text {th }}$ Century). Moscow, Gamma-Press Publ., 2012, pp. 207-235 (in Russian).

44. Znorovszky A.-B. Between Mary and Christ: Depicting Cross-Dressed Saints in the Middle Ages, Doctoral Dissertation. Budapest, Central European University, 2016. 493 p. Available at: https://www.ceu.edu/ sites/default/files/znorovszkyandrea-bianka_0.pdf (accessed 11 January 2019).

Title. Beyond the Borders of Femininity: St. Eugenia and St. Athanasia in Byzantine and Post-Byzantine Art. Author. Jenny P. Albani - Ph. D., architect - art historian. Hellenic Ministry of Culture and Sports, Bouboulinas St., 20, 10682 Athens, Greece. jennyalbani@gmail.com

Abstract. Byzantine written sources contain vitae of holy women, who disguised as monks lived for a long time in monasteries or hermitages. Concealing their gender, they developed exceptional ascetic qualities surpassing their female nature. These legends, probably composed in Egypt, Syria, and Palestine, from the $5^{\text {th }}$ to the $7^{\text {th }}$ century, exist in Greek, Coptic, Syriac, Ethiopic, Arabic, and Latin. After the Arabs conquered these regions, Byzantine hagiography focused on other types of female saints, leaving aside holy cross-dressers.

Several interpretations may be given to monastic disguises adopted by women. Virility has been associated since antiquity with positive qualities, while femininity with weakness and spiritual poverty. Transcending femininity was, according to Church Fathers, the only way for women to find soul salvation. On the other hand, several scholars see in the attitude of these women an attempt to imitate the superior sex and acquire equal status within the patriarchal society. The transvestite holy woman is consequently an ambiguous figure, being at the same time admired and disputed.

This paper addresses issues of gender identity and iconography in Byzantine and Post-Byzantine art $\left(6^{\text {th }}-16^{\text {th }}\right.$ centuries), based on the figure of the transvestite female saint. Using as case studies St. Eugenia and St. Athanasia, it explores the visual language adopted by medieval artists to depict them and argues that the role of the Capital Constantinople was crucial in shaping the iconography of these holy cross-dressers. It also examines the symbolic meaning of portraits of St. Athanasia included in the otherwise conservative iconographic programmes of Byzantine and Post-Byzantine churches in Cyprus, tracing the origins of her particular popularity in the island.

The image of the transvestite female saint in Byzantium challenges the accepted notions of medieval gender identity and invites us to consider an alternative version of the female persona in the Christian East. The examination of medieval depictions of St. Eugenia and St. Athanasia reveals that the iconographic rendering of these holy cross-dressers was by no means established, but rather a field of experimentation for Byzantine and Post-Byzantine painters.

Keywords: St. Eugenia; St. Athanasia; St. Andronikos; Constantinople; Cyprus; holy cross-dressers; monks. 
Название статьи. За пределами женственности: св. Евгения и св. Анастасия в византийском и поствизантийском искусстве.

Сведения об авторе. Албани Дженни - Ph. D., историк искусства. Министерство культуры и спорта Греции, Бубулинас 20, Афины, Греция, 10682. jennyalbani@gmail.com

Аннотация. В византийской агиографии известны жития святых жён, которые, переодевшись монахами, жили в мужских монастырях, скрывая свой пол и становясь мужественными подвижниками. Жития этих святых были написаны в V-VII вв. в Египте, Сирии и Палестине на греческом, сирийском, коптском, эфиопском, арабском и латинском языках. После того как эти территории были завоеваны арабами, в средневизантийский период, агиография переключилась на другие типы женской святости, оставив в стороне этих подвижниц.

Можно по-разному интерпретировать подвиг женщин, переодевшихся монахами. С древности мужество ассоциировалось с положительными качествами, тогда как женственность - со слабостью и духовной нищетой. В соответствии со святоотеческими писаниями преодоление женственности было для женщин единственным путём спасения души. Некоторые исследователи видят в поступках таких святых жён попытку подражать сильному полу и приобрести равный с ним статус в патриархальном обществе. Таким образом, святая жена, переодевшаяся мужчиной, - противоречивая фигура, вызывающая восхищение и в то же время споры.

Цель этой статьи - рассмотреть проблемы гендерной идентичности и иконографии в византийском искусстве VI-XVI вв. на примере святых жён, переодевшихся в мужское платье. Образы св. Евгении и св. Анастасии рассматриваются для исследования процесса создания двойственной гендерной идентичности и визуального языка, использовавшегося для этого византийскими художниками. Показано, что роль столицы, Константинополя, в формировании визуальной идентичности этих святых жён была решающей. Кроме того, исследуется символическое значение изображений св. Афанасии в иконографических программах кипрских церквей византийского и поствизантийского периодов, которые в остальных аспектах достаточно консервативны. Прослеживаются причины особой популярности этой святой на острове.

Изображение святых трансвеститов в Византии ставит под сомнение принятые представления о гендерной идентичности в восточнохристианской культуре и заставляет их пересмотреть. Исследование изображений св. Евгении и св. Анастасии показывает, что иконография этих святых трансвеститов ни в коей мере не была установившейся традицией, а скорее экспериментальным полем для византийских и поствизантийских художников.

Ключевые слова: св. Евгения; св. Анастасия; св. Андроник; Константинополь; Кипр; святые трансвеститы; монахи. 


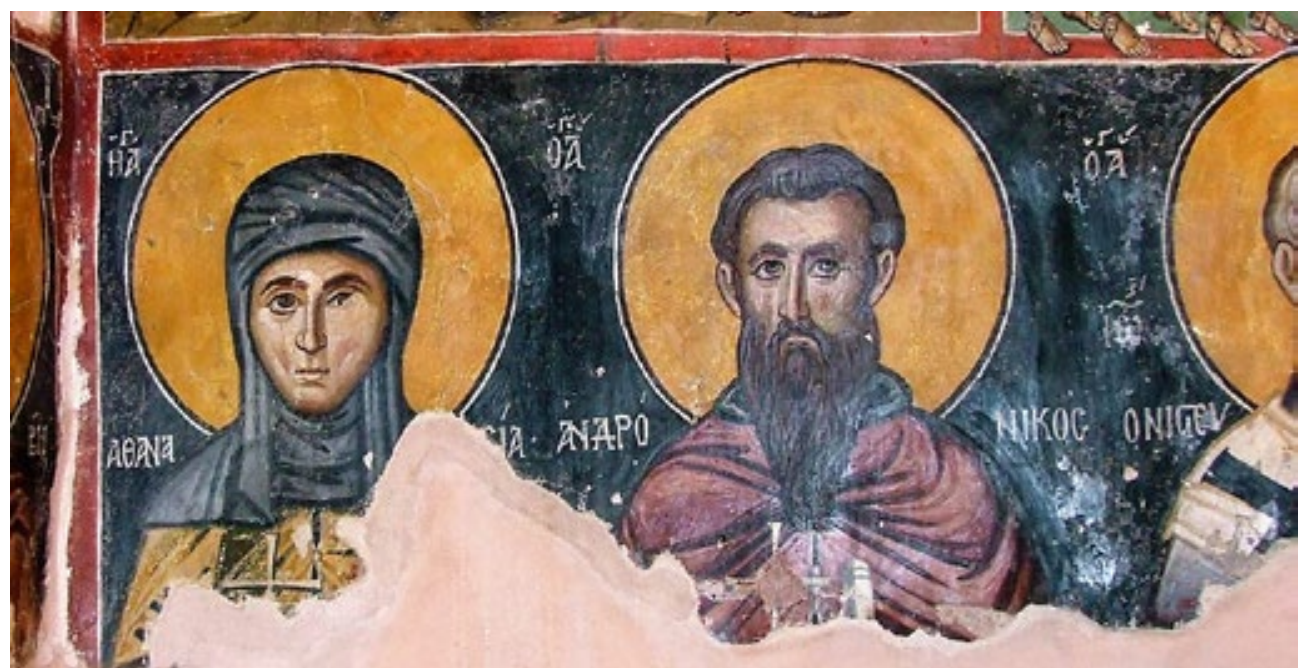

III. 51. St. Andronikos and St. Athanasia. Wall painting. 1495. Church of Hagios Mamas in Louvaras, Cyprus.

(C) Department of Antiquities, Cyprus. Photo by Jenny P. Albani

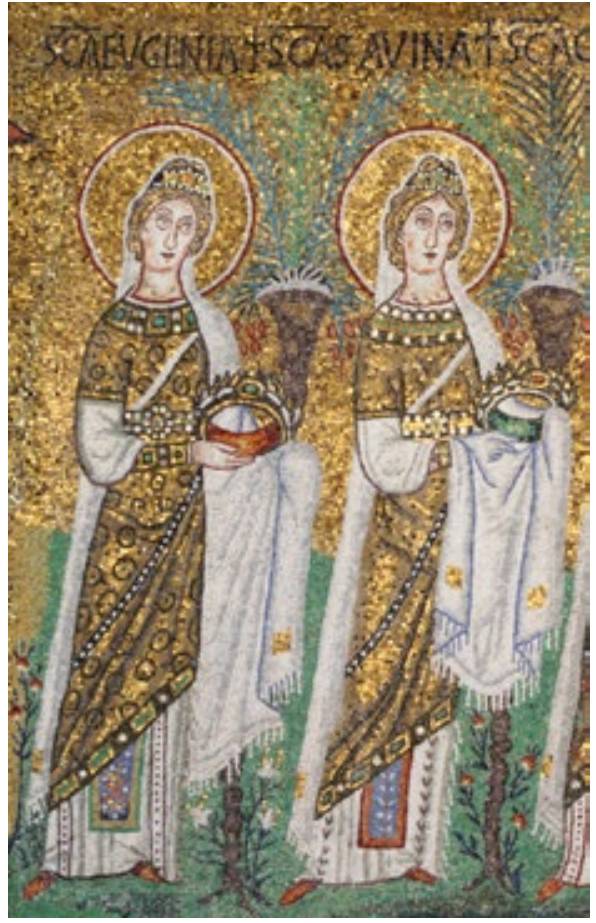

III. 50. St. Eugenia and St. Savina.

Detail of the procession of female martyrs. Mosaic. Ca. 561. Church of Sant' Apollinare Nuovo, Ravenna. Photo by Anna Zakharova

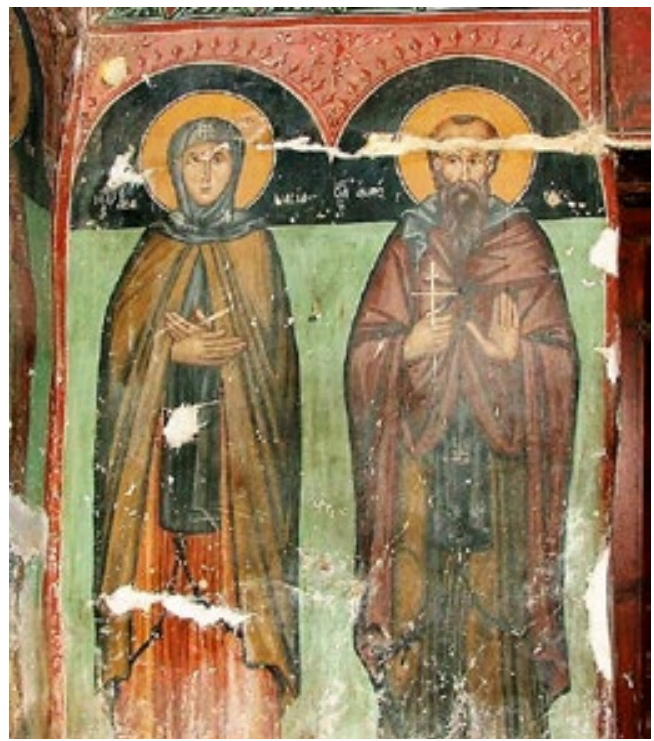

III. 52. Symeon Axentes. St. Andronikos and St. Athanasia. Wall painting. 1514.

Church of Archangelos in Galata, Cyprus. (C) Department of Antiquities, Cyprus. Photo by Jenny P. Albani 